\title{
GAMBARAN PERSEPSI PENYAKIT TERHADAP KESEHATAN FUNGSI PARU PADA PASIEN ASMA DI SURABAYA
}

\section{AN OVERVIEW OF THE PERCEPTION OF LUNG HEALTH IN THE ASTHMA PATIENTS IN SURABAYA}

\author{
Amelia Lorensia ${ }^{1}$, Rivan Virlando Suryadinata ${ }^{2}$, Richa Ratnasari ${ }^{3}$ \\ ${ }^{1}$ Departemen Farmasi Klinis-Komunitas, Fakultas Farmasi, Universitas Surabaya (UBAYA), Surabaya, \\ Indonesia \\ ${ }^{2}$ Departemen Kesehatan Masyarakat, Fakultas Kedokteran, Universitas Surabaya (UBAYA), Surabaya, \\ Indonesia \\ ${ }^{3}$ Mahasiswa Strata-1 Fakultas Farmasi, Universitas Surabaya (UBAYA), Surabaya, Indonesia \\ Alamat Korespondensi: Amelia Lorensia \\ Email: amelia.lorensia@gmail.com
}

\begin{abstract}
ABSTRAK
Penyakit asma dapat mempengaruhi kualitas hidup dan penurunan produktivitas. Perburukan gejala asma juga mempengaruhi fungsi paru. Gejala asma dapat dikontrol dengan manajemen diri. Perilaku pasien dalam manajemen diri tersebut akan sangat dipengaruhi oleh persepsinya terhadap penyakit asma. Penelitian ini bertujuan untuk menganalisis pengaruh persepsi penyakit terhadap kesehatan ungsi paru pada pasien asma di surabaya. Metode penelitian ini adalah observational dengan menggunakan desain cross sectional. Subjek penelitian adalah pasien asma rawat jalan yang berusia 17-25 tahun. Pengumpulan data dilaksanakan pada bulan Juni 2015 sampai Januari 2016 di Surabaya, pada 27 orang. Penilaian persepsi asma dilakukan dengan menggunakan Illness Perception Questionnaire (IPQ) dan kondisi kesehatan fungsi paru dengan alat peak flow meter untuk menilai PEF (peak expiratory flow). Hasil penelitian ini menunjukkan kedua kelompok memiliki nilai PEF $<50 \%$ dari nilai PEF estimasi. Data menunjukkan tidak ada perbedaan signifikan $(\mathrm{p}(0,766)>0,05)$ antara persepsi penyakit berdasarkan jumlah gejala terkait asma dengan fungsi paru (PEF), dengan jawaban terbesar sebagai penyebab asma yaitu keturunan/ genetik. Oleh karena itu, persepsi penyakit asma tidak mempengaruhi fungsi paru (PEF) pada pasien asma usia dewasa di Surabaya.
\end{abstract}

Kata kunci: asma, persepsi penyakit, fungsi paru

\begin{abstract}
Asthma could affect quality of life and decrease productivity. The worsening of asthma symptoms also affected lung function. Symptoms of asthma could be control by self-management. The patient's behavior in selfmanagement influenced by his perception of asthma. This research aims to determine effect of perception of disease on health function of parents in asma patients in surabaya. Research using observational methods with cross sectional design. Research Subjects were outpatient asthma patients aged 17-25 years. Data collection was conducted from June 2015 to January 2016 in Surabaya, to 27 people. Assessment of asthma perception use Illness Perception Questionnaire (IPQ) and health condition of lung function with peak flow meter to assess PEF (peak expiratory flow). The results of this study indicate that both groups have a PEF value $<50 \%$ of the estimated PEF value. The data showed no significant difference $(p(0.766)>0.05)$ between disease perceptions based on the number of asthma-related symptoms with lung function (PEF), with the greatest answer as the cause of asthma that is genetic. Therefore, the perception of asthma does not affect lung function (PEF) in adult asthma patients in Surabaya.
\end{abstract}

Keywords: asthma, illness perception, lung function

\section{PENDAHULUAN}

Asma sering dikenali dari munculnya gejala gangguan pernafasan seperti suara wheezing (mengi), sesak nafas, rasa tertekan di dada dan batuk (Suryadinata et al., 2017). Walaupun mempunyai tingkat fatalitas yang rendah namun jumlah kasusnya cukup banyak ditemukan dalam masyarakat. World Health Organization memperkirakan 100150 juta penduduk dunia menderita asma. Bahkan jumlah ini diperkirakan akan terus bertambah hingga mencapai 180.000 
orang setiap tahun (Global Initiative for Asthma, 2017; DepKes RI, 2009). Di Indonesia, Departemen Kesehatan menyatakan penyakit asma termasuk 10 besar penyebab kesakitan dan kematian, serta diperkirakan $10 \%$ dari 25 juta penduduk Indonesia menderita asma. Prevalensi asma diperkotaan umumnya lebih tinggi dibandingkan dengan di pedesaan, karena pola hidup di kota besar meningkatkan risiko terjadinya asma (Oemiati, 2013). Dampak buruk asma meliputi penurunan kualitas hidup, penurunan produktivitas, ketidakhadiran di sekolah, peningkatan biaya kesehatan, risiko perawatan di rumah sakit dan bahkan kematian (Global Initiative for Asthma, 2017; Lorensia et al, 2011; Lorensia et al, 2015ª).।

Tujuan utama penatalaksanaan asma adalah meningkatkan dan mempertahankan kualitas hidup agar pasien asma dapat hidup normal tanpa hambatan dalam melakukan aktivitas sehari-hari (Global Initiative for Asthma, 2017). Terapi pengobatan asma kini dititikberatkan pada empat komponen penting dalam perawatan asma yaitu penilaian dan pemantauan, pendidikan pasien, kontrol pemicu lingkungan yang mempengaruhi asma pasien, dan obatobatan. Hal ini memberikan pendekatan rinci untuk mencapai gejala asma yang terkontrol dengan baik (Fortenko et al, 2011). Mencapai dan mempertahankan kontrol asma tidak hanya mempertimbangkan dari sisi obat-obatan, namun juga kemampuan pasien dalam manajemen diri (self management) (Pinnock, 2015). Perilaku pasien dalam manajemen diri tersebut akan sangat dipengaruhi oleh persepsinya terhadap penyakit asma.

Hasil dari terapi asma tidak hanya tergantung oleh fungsi paru atau karakteristik biomedis lain, tetapi juga dari persepsi penyakit (illness perception) yang pasien miliki, yang merupakan keyakinan subjektif pasien dan respons emosional terhadap penyakitnya. Illness perception dapat mempengaruhi perilaku dalam mengelola managemen pasien itu sendiri, sehingga mempengaruhi hasil terapi (Lorensia dan Lisiska, 2011).

Persepsi penyakit memiliki andil yang besar untuk hasil terapi, maka persepsi penyakit (illness perception) dapat mencerminkan kontrol pribadi pasien melawan penyakit untuk hasil yang positif (Kaptein et al, 2010). Persepsi penyakit adalah respons individu terhadap penyakit yang terbentuk melalui persepsi individu yang terorganisir dan konsepsi dasar penyakit mereka pada pengalaman dan lingkungan mereka (Yuniarti et al, 2013). Penelitian mengenai peran persepsi penyakit pada kondisi medis telah berkembang dengan pesat dalam beberapa tahun terakhir. Hal ini merupakan awal perkembangan skala untuk mengukur persepsi penyakit dengan Illness Perception Questionnaire (IPQ). Persepsi penyakit telah terbukti memiliki asosiasi yang penting dengan outcome dalam berbagai penyakit akut maupun kronis $(\mathrm{Ng}$, 2012), termasuk asma.

Penelitian mengenai persepsi penyakit di Indonesia, khususnya Surabaya yang sebelumnya dilakukan oleh Lorensia dan Lisiska (2011) dan Lorensia et al (2016), pada pasien asma di suatu suatu rumah sakit dan apotek di kota Surabaya. Namun penelitian tersebut belum melihat kaitan persepsi penyakit dengan kondisi paru pasien asma. Asma ditandai dengan keterbatasan variabel expiratory airflow. fungsi ekspirasi pada paru-paru bervariasi dari waktu ke waktu dan tingkatnya lebih besar daripada di populasi yang sehat (Global Initiative for Asthma, 2017). Fungsi paru tidak terkait dengan pengontrolan asma pada pasien dengan obstruksi aliran udara yang berat. Nilai FEV1 (flow expiratory volume in 1 second) berkorelasi baik dengan gejala asma pada pasien asma yang sulit dengan kontrol yang buruk namun tidak jika kontrol membaik. Kehilangan hubungan ini disebabkan oleh subyek dengan obstruksi aliran udara parah yang parah dimana kontrol subjektif yang 
baik tidak menyingkirkan adanya penyumbatan yang signifikan (Aburuz et al, 2005).

Banyak parameter dan metode untuk menilai faal paru, tetapi yang telah diterima secara luas (standar) dan mungkin dilakukan adalah pemeriksaan spirometri dan peak expiratory flow (PEF) (Lorensia et al, 2015 ${ }^{\mathrm{b}}$ ). Pengukuran PEF secara mandiri dapat berguna dalam manajemen asma, terutama pada mereka dengan persepsi yang buruk terhadap saluran napas mereka sendiri (Roberts et al, 2012). Peak expiratory flow memiliki peran khusus dalam awal penyelidikan kerja asma, di mana fungsi pengujian paru sering diperlukan (Global Initiative for Asthma, 2017). Oleh karena itu, dilakukan penelitian untuk melihat hubungan antara persepsi penyakit asma dan kondisi kesehatan paru dari nilai PEF pada pasien asma dan diharapkan dengan mengetahui perbaikan nilai PEF tersebut maka dapat menjadi masukkan dalam pemberian peyuluhan/pelatihan pada pasien asma dengan karakteristik illness perception yang berbeda

\section{METODE PENELITIAN Desain Penelitian}

Penelitian yang digunakan dalam penelitian ini adalah observational dengan desain cross sectional. Penelitian menggunakan subjek usia 17-25 tahun karena serangan pada usia tersebut lebih berat dan menetap, selain itu pada tingkat pendidikan minimum SMA (sekolah menengah atas) dan mahasiswa di perguruan tinggi karena tingkat pendidikan akan mempengaruhi persepsi seseorang (Adams, 2010; Zimmerman et al, 2014). Penelitian dilakukan di suatu Universitas Swasta di Surabaya, Jawa Timur.

Penilaian pengukuran persepsi penyakit dengan menggunakan Illness Perception Questionnaire (IPQ) dan kondisi kesehatan fungsi paru dengan alat peak flow meter untuk menilai PEF (peak expiratory flow).

\section{Populasi dan Sampel}

Populasi penelitian ini adalah pasien asma rawat jalan. Sedangkan sampel penelitian (responden) adalah pasien asma rawat jalan di Universitas Surabaya yang memenuhi kriteria inklusi dan ekskluasi, dengan metode simple random sampling. Dengan kriteria inklusi: berusia dewasa ( $\geq 18$ tahun) (National Center for Chronic Disease Prevention and Health Promotion, 2011) dan bersedia mengikuti penelitian secara sukarela setelah menerima informed consent. Kriteria eksklusi: (1) Mempunyai penyakit yang dapat mempengaruhi proses pengambilan data; (2) Merokok (Jindal, 2014; ASH, 2015); dan (3) Pasien menggunakan obat asma rutin.

\section{Besar Sampel}

Besar sampel dalam penelitian ini adalah minimal 26 orang. Metode perhitungan besar sampel menggunakan persamaan dari rumus Medical Statistic (Naing et al, 2008):

$\mathrm{n}=\left(\mathrm{Z}^{2} \cdot \mathrm{P} \cdot \mathrm{Q}\right) / \mathrm{d}^{2}$

Bila :

$\mathrm{Z}=1,96$

$\mathrm{P}=0.017$ (RISKESDAS, 2008)

$\mathrm{Q}=1-\mathrm{P}=1-0,0262=0,983$

$\mathrm{d}=0,05$

Maka besar sampel penelitian (n) minimal tiap kelompok dalam penelitian ini adalah $25,67 \sim 26$ orang.

\section{Variabel Penelitian}

Variabel penelitian ini adalah persepsi penyakit dan nilai PEF. Penilaian ini menggunakan kuisioner Illness Perception Questionnaire (IPQ) (Ng, 2012). Kuesioner ini meminta subyek untuk menilai dari serangkaian pernyataan tentang penyakit mereka. Pernyataanpernyataan ini mencerminkan dimensi identitas seperti gejala nyeri dan kelelahan, consequences atau konsekuensi (seperti 'penyakit saya telah memiliki konsekuensi besar pada hidup saya'), time line atau lama 
sakit (seperti 'penyakit saya akan bertahan waktu singkat'), cause atau penyebab (misalnya 'Stres merupakan faktor utama dalam menyebabkan penyakit saya') dan obat/ kontrol (misalnya 'Ada banyak yang bisa saya lakukan untuk mengontrol gejala saya'). Kuesioner ini terdiri dari 9 pertanyaan yang dikelompokkan menjadi 5 domain.

Peak flow meter merupakan alat pengukur peak expiratory flow (PEF). Pengukuran PEF pada penelitian ini menggunakan peak flow meter dari Medical Center Trading Corporation Pioneer St. Cor. Shaw Blvd., Pasig City. PEF (L/menit) dapat menunjukkan tingkat keterbatasan aliran udara (Global Initiative for Asthma, 2017). Responden diminta melakukan pengukuran nilai fungsi paru menggunakan peak flow meter sebanyak 3 kali dan dilihat nilai terbaiknya. Nilai tersebutkan akan dibandingkan dengan nilai estimasi yang akan dihitung berdasarkan jenis kelamin, usia, dan tinggi badan responden, kemudian diklasifikasikan menjadi 3 bagian (Cleveland Clinic, 2017):

Zona hijau : bila nilai PEF 80$100 \%$ dari nilai PEF estimasi

Zona kuning : bila nilai PEF 50$<80 \%$ dari nilai PEF estimasi

Zona merah : bila nilai PEF $<50 \%$ dari nilai PEF estimasi

\section{Metode Pengumpulan Data dan Analisa Data}

Analisis data dalam penelitian ini menggunakan chi-square untuk mengetahui pengaruh persepsi penyakit terhadap kesehatan fungsi paru dari nilai peak flow meter (PEF) pada pasien asma di Surabaya.

\section{HASIL PENELITIAN}

Pengumpulan data dilaksanakan pada bulan Juni 2015 sampai Januari 2016 di Surabaya melalui pengisian kuesioner oleh responden (sampel penelitian). Dalam penelitian ini diperoleh 27 orang responden. Responden dalam penelitian ini dikelompokkan berdasarkan jenis kelamin, umur, dan riwayat pengobatan. Dari 27 pasien didapatkan 7 orang berjenis kelamin pria $(26 \%)$ dan 20 orang berjenis kelamin wanita (74\%) (Tabel 1). Berdasarkan hasil penelitian pada 27 subjek penelitian, diperoleh hasil penelitian mengenai nilai rata-rata PEF (Peak Expiratory Flow) sebesar 217,96 L/detik. Dari 27 pasien, didapatkan bahwa pasien mengalami gejala penyakit paling banyak adalah sesak nafas (26 orang).

Tabel 1. Distribusi Frekuensi Jenis

\begin{tabular}{|c|c|c|c|}
\hline \multirow{2}{*}{\multicolumn{2}{|c|}{$\begin{array}{c}\text { Karakteristik Subjek } \\
\text { Penelitian }\end{array}$}} & \multicolumn{2}{|c|}{ Responden } \\
\hline & & \multirow{2}{*}{$\begin{array}{c}\begin{array}{c}\text { Frekuens } \\
\text { i (n:27) }\end{array} \\
7\end{array}$} & \multirow{2}{*}{$\begin{array}{c}\begin{array}{c}\text { Persentase } \\
(\%)\end{array} \\
26,00\end{array}$} \\
\hline \multirow{2}{*}{$\begin{array}{l}\text { Jenis } \\
\text { Kelam } \\
\text { in }\end{array}$} & Laki-laki & & \\
\hline & Perempuan & 20 & 74,00 \\
\hline $\begin{array}{l}\text { Kateg } \\
\text { ori } \\
\text { Usia } \\
\text { (tahun } \\
\text { ) }\end{array}$ & $\begin{array}{l}\text { Remaja akhir } \\
(17-25)\end{array}$ & 27 & 100,00 \\
\hline \multirow{9}{*}{$\begin{array}{l}\text { Riway } \\
\text { at } \\
\text { pengo } \\
\text { batan } \\
\text { asma }\end{array}$} & $\begin{array}{l}\text { Agonis } \beta-2 \\
\text { kerja singkat } \\
\text { oral }\end{array}$ & 8 & 21,05 \\
\hline & $\begin{array}{l}\text { Agonis } \beta-2 \\
\text { kerja singkat } \\
\text { inhalasi }\end{array}$ & 10 & 26,31 \\
\hline & $\begin{array}{l}\text { Kortikosteroi } \\
\text { d oral }\end{array}$ & 1 & 2,63 \\
\hline & $\begin{array}{l}\text { Kortikosteroi } \\
\text { d inhalasi }\end{array}$ & 1 & 2,63 \\
\hline & $\begin{array}{l}\text { Agonis } \beta-2 \\
\text { kerja lama } \\
\text { inhalasi }\end{array}$ & 2 & 5,28 \\
\hline & $\begin{array}{l}\text { Metilsantin } \\
\text { oral }\end{array}$ & 4 & 10,53 \\
\hline & Oksigen & 1 & 2,63 \\
\hline & Lain-lain & 8 & 21,05 \\
\hline & $\begin{array}{l}\text { Tidak sedang } \\
\text { menggunaka } \\
\text { n obat } \\
\text { apapun }\end{array}$ & 3 & 7,89 \\
\hline
\end{tabular}

Kelamin Sampel Penelitian 
Zona nilai PEF terbanyak adalah zona merah $(66,67 \%)$ yang berarti nilai PEF $<50 \%$ dari nilai PEF estimasi. Uji chisquare melihat pengaruhi persepsi penyakit berdasarkan zona nilai PEF (dibagi menjadi 2: hijau-kuning dan merah) dengan jumlah gejala terkait asma (dibagi menjadi 3: jumlah gejala 2, 3, dan $4)$, dengan nilai $p(0,766)>0,05$ yang berarti tidak ada perbedaan signifikan antara persepsi penyakit berdasarkan jumlah gejala terkait asma dengan fungsi paru (Tabel 2). Keterangan : Jumlah gejala asma, merupakan total dari 4 gejala asma yang terdiri dari: sesak nafas, lelah, mengi, dan sulit tidur. Perhitungan nilai $p$ membandingkan antar kelompok Zona Nilai PEF (hijau-kuning dan merah), dan jumlah gejala terkait asma (2,3, dan 4).

Tabel 2. Pengaruh Persepsi Penyakit Berdasarkan Jumlah Gejala terkait Asma dengan Fungsi Paru dari Nilai Peak Expiratory Flow (PEF)

\begin{tabular}{ccccccc}
\hline $\begin{array}{c}\text { Jumlah gejala } \\
\text { terkait asma }\end{array}$ & \multicolumn{3}{c}{ Zona Nilai PEF } & TOTAL & Nilai & Kesimpulan \\
\cline { 2 - 5 } & $\begin{array}{c}\text { Hijau } \\
(\mathbf{n : 1})\end{array}$ & $\begin{array}{c}\text { Kuning } \\
(\mathbf{n : 8})\end{array}$ & $\begin{array}{c}\text { Merah } \\
(\mathbf{n : 1 8})\end{array}$ & & & \\
\hline 2 & 0 & 1 & 4 & $\mathbf{5}$ & 0,766 & $\begin{array}{l}\text { Tidak ada } \\
\text { perbedaan } \\
\text { signifikan }\end{array}$ \\
\hline 3 & 0 & 3 & 6 & $\mathbf{9}$ & & \\
\hline 4 & 1 & 4 & 8 & $\mathbf{1 3}$ & & \\
\hline
\end{tabular}

Tabel 3. Pengaruh Persepsi Penyakit Berdasarkan Penyakit Asma dengan Fungsi Paru dari Nilai Peak Expiratory Flow (PEF)

\begin{tabular}{|c|c|c|c|c|c|c|c|}
\hline \multirow{2}{*}{\multicolumn{3}{|c|}{$\begin{array}{c}\text { Klasifikasi Illness Perception mengenai } \\
\text { Penyakit Asma }\end{array}$}} & \multicolumn{3}{|c|}{ Zona Nilai PEF } & \multirow{3}{*}{$\begin{array}{c}\text { TOTAL } \\
\text { (n:27) } \\
6\end{array}$} & \multirow{3}{*}{$\begin{array}{c}\text { Nilai } \\
\mathbf{P} \\
0,772\end{array}$} \\
\hline & & & \multirow{2}{*}{$\begin{array}{c}\begin{array}{c}\text { Hijau } \\
(\mathbf{n : 1})\end{array} \\
0\end{array}$} & \multirow{2}{*}{$\begin{array}{c}\begin{array}{c}\text { Kuning } \\
\text { (n:8) }\end{array} \\
2\end{array}$} & \multirow{2}{*}{$\begin{array}{c}\begin{array}{c}\text { Merah } \\
\text { (n:18) }\end{array} \\
4\end{array}$} & & \\
\hline \multirow[t]{3}{*}{ B1 } & \multirow{3}{*}{$\begin{array}{l}\text { Kaitan } \\
\text { Aktivitas Fisik } \\
\text { dengan } \\
\text { Penyakit Asma } \\
\text { (Consequneces) }\end{array}$} & $\begin{array}{l}\text { Tidak } \\
\text { mempengaruhi }\end{array}$ & & & & & \\
\hline & & Ragu-ragu & 0 & 1 & 1 & 2 & \\
\hline & & Mempengaruhi & 1 & 5 & 13 & 19 & \\
\hline \multirow[t]{3}{*}{$\mathbf{B 2}$} & \multirow{3}{*}{$\begin{array}{l}\text { Lama Penyakit } \\
\text { Asma } \\
\text { (Timeline) }\end{array}$} & $\begin{array}{l}\text { Hanya beberapa } \\
\text { hari/bulan }\end{array}$ & 0 & 0 & 3 & 3 & 0,382 \\
\hline & & Ragu-ragu & 1 & 3 & 5 & 9 & \\
\hline & & $\begin{array}{l}\text { Beberapa tahun/ } \\
\text { selamanya }\end{array}$ & 0 & 5 & 10 & 15 & \\
\hline \multirow[t]{3}{*}{ B3 } & \multirow{3}{*}{$\begin{array}{l}\text { Kontrol } \\
\text { Penyakit Asma } \\
\text { (Personal } \\
\text { Control) }\end{array}$} & Kurang terkontrol & 1 & 3 & 5 & 9 & 0,636 \\
\hline & & Ragu-ragu & 0 & 1 & 4 & 5 & \\
\hline & & Terkontrol & 0 & 4 & 9 & 13 & \\
\hline \multirow[t]{3}{*}{ B4 } & \multirow{3}{*}{$\begin{array}{l}\text { Pengobatan } \\
\text { yang dilakukan } \\
\text { pasien } \\
\text { (Treatment } \\
\text { Control) }\end{array}$} & $\begin{array}{l}\text { Tidak } \\
\text { mmembantu }\end{array}$ & 0 & 2 & 3 & 5 & 0,310 \\
\hline & & Ragu-ragu & 0 & 3 & 2 & 5 & \\
\hline & & Membantu & 1 & 3 & 13 & 17 & \\
\hline \multirow[t]{4}{*}{ B5 } & \multirow{4}{*}{$\begin{array}{l}\text { Frekuensi } \\
\text { Mengalami } \\
\text { Gejala Asma } \\
\text { (Identity) }\end{array}$} & $\begin{array}{l}\text { Tidak } \\
\text { pernah/jarang (1- } \\
\text { 2x dalam sebulan) }\end{array}$ & 0 & 0 & 4 & 4 & 0,305 \\
\hline & & Ragu-ragu & 1 & 7 & 13 & 21 & \\
\hline & & Sering/ (1-2x & 0 & 1 & 1 & 2 & \\
\hline & & 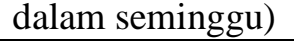 & 0 & 0 & 0 & $\mathbf{0}$ & \\
\hline \multirow[t]{2}{*}{ B6 } & \multirow{2}{*}{$\begin{array}{l}\text { Kecemasan } \\
\text { terhadap }\end{array}$} & \multirow{2}{*}{ Tidak kuatir } & 0 & 0 & 1 & 1 & 0,960 \\
\hline & & & 0 & 5 & 8 & 13 & \\
\hline
\end{tabular}




\begin{tabular}{|c|c|c|c|c|c|c|c|}
\hline \multirow{2}{*}{\multicolumn{3}{|c|}{$\begin{array}{c}\text { Klasifikasi Illness Perception mengenai } \\
\text { Penyakit Asma }\end{array}$}} & \multicolumn{3}{|c|}{ Zona Nilai PEF } & \multirow{2}{*}{$\begin{array}{l}\text { TOTAL } \\
(\mathbf{n}: 27)\end{array}$} & \multirow{4}{*}{$\begin{array}{l}\text { Nilai } \\
\mathbf{P}\end{array}$} \\
\hline & & & $\begin{array}{c}\text { Hijau } \\
(n: 1)\end{array}$ & $\begin{array}{c}\text { Kuning } \\
(\mathbf{n}: 8)\end{array}$ & $\begin{array}{l}\text { Merah } \\
(\mathbf{n}: 18)\end{array}$ & & \\
\hline & \multirow{2}{*}{$\begin{array}{l}\text { Penyakit Asma } \\
\text { (Concern) }\end{array}$} & Ragu-ragu & 1 & 0 & 2 & 3 & \\
\hline & & Kuatir & 0 & 3 & 7 & 10 & \\
\hline \multirow[t]{3}{*}{ B7 } & \multirow{3}{*}{$\begin{array}{l}\text { Pemahaman } \\
\text { Penyakit Asma } \\
\text { (Understanding) }\end{array}$} & Tidak mengerti & 1 & 2 & 4 & 7 & \multirow[t]{3}{*}{0,808} \\
\hline & & Ragu-ragu & 0 & 1 & 3 & 4 & \\
\hline & & Mengerti & 0 & 5 & 11 & 16 & \\
\hline \multirow[t]{3}{*}{ B8 } & \multirow{3}{*}{$\begin{array}{l}\text { Pengaruh asma } \\
\text { terhadap Emosi } \\
\text { (Emotional } \\
\text { Response) }\end{array}$} & $\begin{array}{l}\text { Tidak membuat } \\
\text { emosi }\end{array}$ & 1 & 3 & 6 & 10 & \multirow[t]{3}{*}{0,732} \\
\hline & & Ragu-ragu & 0 & 2 & 3 & 5 & \\
\hline & & Membuat emosi & 0 & 3 & 9 & 12 & \\
\hline \multirow[t]{3}{*}{ B9 } & \multirow{3}{*}{$\begin{array}{l}\text { Pengaruh asma } \\
\text { terhadap } \\
\text { Kondisi } \\
\text { Keuangan }\end{array}$} & $\begin{array}{l}\text { Tidak } \\
\text { mempengaruhi }\end{array}$ & 1 & 5 & 13 & 18 & \multirow[t]{3}{*}{0,618} \\
\hline & & Ragu-ragu & 0 & 1 & 2 & 3 & \\
\hline & & Mempengaruhi & 0 & 3 & 3 & 6 & \\
\hline
\end{tabular}

Nilai $\mathrm{P}>0,05$ artinya tidak ada perbedaan signifikan

Pada Tabel 3, menunjukkan pengaruh persepsi penyakit berdasarkan penyakit asma dengan nilai PEF. Persepsi penyakit berdasarkan penyakit asma, dipengaruhi oleh aktivitas fisik, lama penyakit asma, kontrol penyakit asma, pengobatan yang dilakukan oleh pasien, pemahaman penyakit asma, dan pengaruh asma terhadap emosi. Namun tidak ada dimensi persepsi penyakit yang mempengaruhi nilai PEF. Tiga jawaban terbesar sebagai penyebab asma menurut responden yang menyebabkan penyakit asma, yaitu keturunan/ genetik, kuman/virus/infeksi, dan kekebalan tubuh menurun (Tabel 4). Namun tidak ada persepsi penyakit berdasarkan penyebab asma yang mempengaruhi nilai PEF.

Tabel 4. Pengaruh Persepsi Penyakit Berdasarkan Penyebab Penyakit Asma dengan Fungsi Paru dari Nilai Peak Expiratory Flow (PEF)

\begin{tabular}{|c|c|c|c|c|c|c|c|}
\hline \multirow{2}{*}{\multicolumn{3}{|c|}{$\begin{array}{c}\text { Illness Perception mengenai Penyebab } \\
\text { Asma }\end{array}$}} & \multicolumn{3}{|c|}{ Zona Nilai PEF } & \multirow{3}{*}{$\begin{array}{c}\begin{array}{c}\text { TOTAL } \\
\text { (n:27) }\end{array} \\
4 \\
\end{array}$} & \multirow{2}{*}{$\begin{array}{c}\text { Nilai } \\
\mathbf{P}\end{array}$} \\
\hline & & & \multirow{2}{*}{$\begin{array}{c}\begin{array}{c}\text { Hijau } \\
(\mathbf{n}: 1)\end{array} \\
1 \\
\end{array}$} & \multirow{2}{*}{$\begin{array}{c}\text { Kuning } \\
\text { (n:8) }\end{array}$} & \multirow{2}{*}{$\begin{array}{c}\begin{array}{c}\text { Merah } \\
\text { (n:18) }\end{array} \\
1 \\
\end{array}$} & & \\
\hline \multirow{3}{*}{$\mathrm{C} 2$} & \multirow{3}{*}{$\begin{array}{l}\text { Keturunan/ } \\
\text { genetik }\end{array}$} & Tidak setuju & & & & & \multirow[t]{3}{*}{0,050} \\
\hline & & Ragu-ragu & 0 & 1 & 0 & 1 & \\
\hline & & Setuju & 0 & 5 & 17 & 21 & \\
\hline \multirow{3}{*}{$\mathrm{C3}$} & \multirow{3}{*}{$\begin{array}{l}\text { Kuman, virus, } \\
\text { infeksi }\end{array}$} & Tidak setuju & 0 & 1 & 1 & 2 & \multirow[t]{3}{*}{0,685} \\
\hline & & Ragu-ragu & 1 & 2 & 4 & 7 & \\
\hline & & Setuju & 0 & 5 & 13 & 18 & \\
\hline \multirow{3}{*}{ C7 } & \multirow{3}{*}{$\begin{array}{l}\text { Kekebalan tubuh } \\
\text { menurun }\end{array}$} & Tidak setuju & 0 & 0 & 0 & $\mathbf{0}$ & \multirow[t]{3}{*}{0,542} \\
\hline & & Ragu-ragu & 1 & 2 & 4 & 7 & \\
\hline & & Setuju & 0 & 6 & 14 & 20 & \\
\hline
\end{tabular}

Nilai $\mathrm{P}>0,05$ artinya tidak ada perbedaan signifikan

\section{PEMBAHASAN}

Pengukuran terhadap illness perception dapat digambarkan dengan lima dimensi dalam cognitive representation of illness antara lain: (1) Identify (label pasien yang digunakan untuk menggambarkan illness dan gejala yang mereka alami sebagai bagian dari penyakit (disease)); (2) Consequences (efek yang diharapkan dan outcomes dari illness); (3) Cause (ide personal mengenai penyebab dari penyakit); (4) Timeline (berapa lama pasien mempercayai bahwa penyakitnya akan berlangsung); dan (5) Cure atau Control (menjelaskan apa yang dipercayai pasien bahwa mereka dapat pulih atau sembuh dari 
penyakitnya) (Broadbent et al., 2006; Ittersum et al., 2009; Moss-Morris et al., 2002). Lima dimensi tersebut adalah:

Label/ gejala yang digunakan untuk menggambarkan penyakitnya (identity). Hasil penelitian menunjukkan bahwa persepsi secara subjektif terhadap gejala penyakit yang sebagian besar dialami pasien asma yaitu: sesak nafas $(96,30 \%)$, mengi $(95,59 \%)$, lelah $(85,19 \%)$, dan sulit tidur $(77,78 \%)$. Hal ini sesuai dengan gejala asma yang memang terjadi. Suara mengi (whistling sound) ini disebabkan karena terjadinya gangguan pada saluran pernafasan atau produksi mukus berlebihan. Jika terjadi kesulitan dalam bernafas, maka sel-sel tubuh mengalami kekurangan suplai $\mathrm{O}_{2}$, yang dapat menyebabkan sulit tidur atau terbangun pada malam hari, selain itu juga menyebabkan tubuh menjadi lelah. Sedangkan sakit tenggorokan, mual, sakit perut, kaku sendi, sakit mata, sakit kepala, pusing, dan berat badan turun adalah gejala yang tidak berkaitan dengan penyakit asma. Namun, kemungkinan gejala-gejala ini dapat disebabkan oleh efek samping obat yang digunakan oleh pasien (Kelly dan Sorkness, 2011).

Dampak dan hasil dari penyakit (consequences). Sebagian besar sampel penelitian $(66,67 \%)$ menjawab bahwa penyakit asma mempengaruhi aktivitas. Dalam kenyataannya, pasien asma memang memiliki keterbatasan dalam beraktivitas. Oleh karena itu apabila telah diketahui aktivitas apa saja yang dapat menyebabkan asma, sebaiknya pasien diberikan konseling untuk meminum obatnya terlebih dahulu sebagai pencegahan terjadinya serangan asma (Global Initiative for Asthma, 2017). Penyebab penyakitnya (cause of illness). Hasil penelitian menunjukkan bahwa tiga faktor tertinggi penyebab penyakit asma mereka berturut-turut adalah faktor keturunan, virus, kuman dan bakteri dan kekebalan tubuh yang menurun. Faktor keturunan/genetik adalah riwayat penyakit keluarga pasien yang pernah menderita asma. Faktor keturunan/genetik memang merupakan salah satu dari penyebab asma yang dominan. Beberapa virus penyebab infeksi seperti rhinovirus memiliki hubungan terhadap kekambuhan mengi (wheezing) pada masa anak-anak. Namun kenyataannya mengi pada usia dewasa terjadi karena bermacam-macam kondisi dan tidak semua kondisi mengi pada usia dewasa merupakan suatu indikasi terjadinya asma (Global Initiative for Asthma, 2017). Lama penyakit asma akan berlangsung (timeline). Penyakit asma tidak mengenal kata "sembuh", karena tidak dapat disembuhkan dan dapat muncul sewaktu-waktu. Gejala asma dapat berlangsung selamanya (Global Initiative for Asthma, 2017). Hasil penelitian menunjukkan bahwa hanya sedikit pasien (9 dari 27 orang) yang mengetahui penyakit asma akan berlangsung selamanya. Banyak dari subjek penelitian belum mengetahui bahwa penyakit asmanya bisa muncul setiap saat dan tidak terduga.

Pengobatan yang dapat membantu penyakitnya (cure or control). Hasil penelitian menunjukkan bahwa sebagian besar pasien (11 dari 27 pasien) mengatakan penyakit asmanya sudah terkontrol. Pasien berpendapat bahwa pengobatan yang digunakan membantu mengatasi serangan asmanya (16 dari 27 orang). Hal ini merupakan salah satu ciri asma yang terkontrol (Global Initiative for Asthma, 2017). Namun menunjukkan sebagian besar pasien mengatakan ragu atau tiba-tiba muncul gejala asma (22 dari 27 orang). Kelima dimensi diatas telah mengungkapkan berbagai macam persepsi sakit pasien. Persepsi sakit pasien mengenai consequences, cause of illness, timeline, dan cure or control sudah baik, namun pada dimensi identity sebagian besar responden masih ragu-ragu mengenai gejala asmanya.

Pengukuran fungsi paru pada penelitian ini menilai PEF (peak expiratory flow) dengan peak flow meter dengan jenis dan merek yang sama. Kondisi pasien yang sedang mengalami eksaserbasi asma juga mempengaruhi kemampuan subjek penelitian saat meniup peak flow meter karena alat tersebut akan dipengaruhi jumlah udara yang dihirup (inspirasi) dan jumlah udara yang dihembuskan (ekspirasi), sedangkan pada saat pasien yang mengalami eksaserbasi asma pasien mengalami gangguan keterbatasan dalam ekspirasi (Global Initiative for Asthma, 2017). Selain itu, faktor-faktor lain yang dapat mempengaruhi pengukuran PEF, seperti: kondisi gejala asma (Medscape, 2017), obesitas (Ilango et al, 2014; Goswami et al, 2014). Pada penelitian ini tidak dilakukan pemeriksaan prediksi nilai terbaik, karena pasien pertama kali menggunakan alat sehingga hanya menggunakan nilai prediksi dari tinggi badan rata-rata orang Indonesia yaitu untuk laki-laki sebesar $162,5 \mathrm{~cm}$ dan 
untuk perempuan 151,2 cm (Sohn, 2015). Pengukuran nilai terbaik pasien bukanlah merupakan parameter nilai terbaik penilaian fungsi paru, karena nilai terbaik pasien seharusnya berasal dari nilai pada saat pperburukan asma atau munculnya gejala asma, dan nilai tersebut digunakan sebagai patokan untuk mengetahui variabilitas kontrol asma pasien dengan acuan bila nilai PEF kurang dari $80 \%$ nilai terbaik pasien maka pasien berisiko mengalami eksaserbasi asma atau eksaserbasi berulang (Global Initiative for Asthma, 2017).

Keterbatasan penelitian antara lain: (1) Pengukuran nilai PEF tidak dari nilai terbaik pasien asma.; (2) Kriteria inklusi sampel penelitian seperti data riwayat jantung dan ginjal tidak diperoleh secara akurat. Karena saat sampel penelitian mengatakan bahwa tidak ada riwayat jantung dan ginjal tidak didukung oleh hasil pengecekan dokter terlebih dahulu; dan (3) Dilihat dari obat (reliever) yang digunakan sampel penelitian pada penelitian ini dapat dikategorikan, sampel memiliki step asma yang sama yaitu diantara step 1 sampai step 2 namun hal ini tidak didukung oleh pemeriksaan dokter yang terbaru.

\section{SIMPULAN}

Persepsi penyakit tidak mempengaruhi fungsi paru dari nilai peak expiratory flow pada pasien asma usia dewasa di Surabaya.

\section{DAFTAR PUSTAKA}

Aburuz S, McElnay J, Gamble J, Millership J, Heaney L. 2005. Relationship between lung function and asthma symptoms in patients with difficult to control asthma. J Asthma, 42(10):85964.

https://doi.org/10.1080/0277090050037 1187

Adams RJ. 2010. Improving health outcomes with better patient understanding and education. Risk Manag Healthc Policy, 3:61-72. https://doi.org/10.2147/RMHP.S7500

ASH. Action on Smoking and Health. 2015. ASH Research Report: Asthma and Smoking, (online),

Broadbent E, Petrie KJ, Main J, Weinman J. 2006. The Brief Illness Perception
Questionnaire. Journal of

Psychosomatic Research, 60:631- 637. https://doi.org/10.1016/j.jpsychores.200 5.10 .020

Cleveland Clinic. 2017. How to Use a Peak Flow Meter, (online),

Departemen Kesehatan RI. 2009. Pedoman Pengendalian Penyakit Asma. Jakarta: Direktorat Jenderal PP \& PL Departemen Kesehatan.

Fortenko O, Zeki A, Schuster G, Davis C, Allayee H, Stephensen C. et al. 2011. Asthma patients with specific genotypes identified for fish oil. California Agriculture, $\quad$ 65(3):112-117. https://doi.org/10.3733/ca.v065n03p112

Global Initiative for Asthma (GINA). 2017. Global Strategy for Asthma Management \& Prevention (Update), (Online),

Goswami B, Roy AS, Dalui R, Bandyopadhyay A. 2014. Peak Expiratory Flow Rate - A Consistent Marker of Respiratory Illness Associated with Childhood Obesity. American Journal of Sports Science and Medicine, 2(1):21-26. https://doi.org/10.12691/ajssm-2-5A-8

Ilango S, Cristy A, Saravanan A, Sembulingam P. 2014. Correlation of Obesity Indices with Peak Expiratory Flow Rate in Males and Females. IOSR Journal Of Pharmacy, 4(2):21-27. https://doi.org/10.9790/3013040202021-27

Ittersum MW, Wilgen CP, Hilberdink WKHA, Groothoff JW, Illness perceptions in patients with fibromyalgia. Chapter 4. Patient Educ Couns, 74(1):53-60. https://doi.org/10.1016/j.pec.2008.07.04 1

Jindal SK. 2014. Effects of Smoking on Asthma. Supplement to Journal of The Association of Physicians of India, 62:32-37.

Kapteina, A.A, Klokb, T., Moss-Morrisc, R., Brand, P. 2010. Illness perceptions: impact on self-management and control in asthma. Current Opinion in Allergy and Clinical Immunology, 10:194-199. https://doi.org/10.1097/ACI.0b013e3283 3950c1

Kelly HW, Sorkness C. 2011. Asthma. Dalam DiPiro J, Talbert R, Yee G, Matzke G, Wells B, Posey M. editors. 
Pharmacotherapy: A Pathophysiologic Approach, $8^{\text {th }}$ ed. McGrawHill. New York. US.

Lorensia A, Lisiska N. 2011. Illness Perceptions Study of Asthma Treatment Compliance in Pharmaceutical Care. Jurnal ANIMA Indonesian Psychological Journal, 26(3):184-188. https://doi.org/10.25026/jtpc.v1i3.26

Lorensia A, Wahjuningsih E, Canggih B, Lisiska N. 2011. Pharmacist's Strategies in Treating Asthma Bronchiale Outpatient. Jurnal of Tropical Pharmacy and Chemistry, UNMUL, 1(3):177-191.

Lorensia A, Wahjuningsih E, Sungkono EP. 2015. Hubungan Pengaruh Tingkat Keparahan Asma dengan Kualitas Hidup dalam Memicu Timbulnya Depresi pada Pasien Asma Kronis. Jurnal Ilmiah Sains \& Teknologi UBAYA, 8(2):21-30.

Lorensia A, Queljoe DD, Santosa KA. 2015 . Kelengkapan Informasi Mengenai Cara Penggunaan Peak Flow Meter yang Diberikan kepada Pasien Asma di Apotek. Jurnal Ilmiah Manuntung (JIM) Sains Farmasi dan Kesehatan, Akademi Farmasi Samarinda, 1(2):8-18.

Lorensia A, Yulia R, Wahyuningtyas IS. 2016. Hubungan Persepsi Penyakit (Illness Perception) dengan Kontrol Gejala Asma pada Pasien Rawat Jalan. Media Pharmaceutica Indonesiana (MPI), 1(2):92-99.

https://doi.org/10.24123/mpi.v1i2.191

Medscape. 2017. Peak Flow Rate Measurement, (online),

Moss-Morris R, Weinmann J, Petrie KJ, Horne R, Cameron LD, Buick D. 2002. The Revised Illness Perception Questionnaire (IPQ-R). Psychology and Health, $17(1): 1-16$. https://doi.org/10.1080/0887044029000 1494

Naing, L., Win, T., Rusli, B.N. 2008. Medical Statistic: Practical Issues in Calculating the Sample Size for Prevence Studies, Archives of Orofacial Sciences 2006; 1:9-14.

National Center for Chronic Disease Prevention and Health Promotion. 2011, Data Source with Asthma Content: Behavioral Risk Factor Surveillance System (BRFSS), (Online), (https://www.cdc.gov/asthma/survey/brf ss.pdf), 24 September 2017.

$\mathrm{Ng}$ TS. 2012. Brief Illness Perception Questionnaire (Brief IPQ). Journal of Physiotherapy, $58: 202$. https://doi.org/10.1016/S18369553(12)70116-9

Oemiati R. 2013. Faktor-faktor yang Berhubungan dengan Penyakit Asma di Indonesia. Media Litbang Kesehatan, 20(1):41-49.

Pinnock H. 2015. Supported Self-Management for Asthma. Breathe (Sheff), 11(2):98109. https://doi.org/10.1183/20734735.01561 4

RISKESDAS. 2008. Laporan Riset Kesehatan Daerah (RISKESDAS) 2007. Litbang Depkes.

Roberts MH, Mapel DW. 2012. Limited Lung Function: Impact of Reduced Peak Expiratory Flow on Health Status, Health-Care Utilization, and Expected Survival in Older Adults. Am $J$ Epidemiol, 176(2): 127-134. https://doi.org/10.1093/aje/kwr503

Sohn, K. 2015. The Height Premium in Indonesia. Economics \& Human Biology, $\quad 16: 1-15$. https://doi.org/10.1016/j.ehb.2013.12.01 1

Suryadinata RV., Lorensia A., Aprilia AP. 2017. Profil vitamin d pada pasien asma dan non-asma dewasa di Surabaya. The Indonesian Journal of Public Health. 12(1):106-117. https://doi.org/10.20473/ijph.v12i1.20 17.106-117

Yuniarti KW, Dewi C, Ningrum RP, Widiastuti M, Asril NM. 2013. Illness perception, stress, religiosity, depression, social support, and self management of diabetes in Indonesia. International Journal of Research Studies in Psychology, 2(1):25-41. https://doi.org/10.5861/ijrsp.2012.185

Zimmerman EB, Woolf SH, Haley A. 2014. Understanding the Relationship Between Education and Health: A Review of the Evidence and an Examination of Community Perspectives. The National Academy of Sciences,(online),https://doi.org/10.3147 8/201406a 